\title{
Evaluation of Swamp Taro [Colocasia esculenta var. Stoloniferum (L.) Schott] Germplasms on Physiology, Yield and Quality
}

\author{
Joyshree Laishram*, A.K. Bijaya Devi, K. James Singh and Lourembam Tinibala Devi \\ Department of Horticulture, College of Agriculture, Central Agricultural University, \\ Imphal, Manipur-795004, India \\ *Corresponding author
}

\section{A B S T R A C T}

Keywords

Swamp taro, Caudex, Yield,

Starch and dry matter content

Article Info

Accepted:

10 June 2019

Available Online:

10 July 2019
A field experiment was conducted at experimental field of College of Agriculture, Central Agricultural University, Imphal, Manipur during 2017-2018. The experiment was laid out in Randomized Block Design with three replications. The treatment consisted of nine germplasms: CAUST-1, CAUST-2, AAUST-1, AAUST-2, AAUST-3, BCST-1, BCST-3, BCST-5 and BCST-13.The results of the experiment revealed that among the nine entries of swamp taro, the physiological parameters at 120 days after planting viz., leaf area index (0.98), harvest index $(77.67 \%)$, net assimilation rate $\left(0.00060 \mathrm{~g} / \mathrm{m}^{2} /\right.$ day $)$, crop growth rate $\left(1.249 \mathrm{~g} / \mathrm{m}^{2} /\right.$ day $)$ and relative growth rate $(0.0049 \mathrm{~g} / \mathrm{g} /$ day $)$ were highest in CAUST-1. CAUST-1 exhibited the maximum caudex length $(30 \mathrm{~cm})$, caudex diameter $(6.44 \mathrm{~cm})$ and caudex yield/plot $(19.57 \mathrm{~kg})$ while the treatment CAUST2 recorded the maximum number of stolons (8.60) and maximum stolon length was recorded from BCST-1 $(64.71 \mathrm{~cm})$. Maximum stolons weight was recorded from CAUST-2 (194.49g). Quality analysis revealed CAUST-1 was the richest source of starch $(8.77 \%)$ followed by AAUST-3 (7.86 \%), while AAUST-1 registered the maximum dry matter content $(15.99 \%)$.

\section{Introduction}

Tuber crops constitute a major component of food for indigenous and tribal people throughout the world. They play a crucial role in providing food security for about 2.2 billion people in the world besides contributing to animal feeds and industry. Swamp taro [Colocasia esculenta var. stoloniferum (L.) Schott], is one of the important herbaceous tuber vegetable crop. In Manipur, it is locally known as 'pallukabi' and in Assam and Bangladesh, it is also known as 'nalkachu', 'panikachu', 'lati' or 'kachu lati'. Swamp taro can be cultivated with minimum effort and it can sustain growth in waterlogged environment, tolerate brief submergence (Roy Chowdhury et al., 2010). So this crop is easily cultivated in low lying areas where other vegetable crops cannot be grown. Swamp taro 
is grown primarily as a vegetable food for its edible caudex as well as stolon. But depending on varieties, entire plant parts from leaves, petioles, stolon or runners are consumed as green vegetable especially in states like Assam, Bihar, eastern Uttar Pradesh and West Bengal (Saud and Baruah, 2000). Swamp taro contributes to the total supply of bulky vegetables during the summer when the supply of other vegetables becomes scarce in the market. Hence, Evaluation of swamp taro germplasms is essential for identification of high growth rate, high yielding, location specific varieties or germplasms with better quality is the need of the hour.

\section{Materials and Methods}

The experiment was conducted at experimental field of College of Agriculture, Central Agricultural University, Imphal, Manipur during 2017-2018. The experimental site is located at $24^{\circ} 45^{\circ} \mathrm{N}$ latitude and $93^{\circ}$ 56' E longitude at an altitude of $790 \mathrm{~m}$ above the mean sea level. The soil of the experimental field was clay in nature having acidic reaction ( $\mathrm{pH} 5.57)$, high in organic carbon $(0.9 \%)$, medium in available nitrogen $(288.5 \mathrm{~kg} / \mathrm{ha})$, low available phosphorus (18.8 $\mathrm{kg} / \mathrm{ha})$ and available potassium (223.1 $\mathrm{kg} / \mathrm{ha}$ ). The experiment consisting of nine treatment and was laid out in Randomized Block Design with three replications. The treatment consisted of nine germplasms: CAUST-1, CAUST-2, AAUST-1, AAUST-2, AAUST-3, BCST-1, BCST-3, BCST-5 and BCST-13.

The parameters recorded in the study are as follows:

\section{Physiological parameters}

\section{Leaf area index}

Leaf area index is the ratio between total leaf area to canopy of the plant. Leaf area index was calculated at 120 DAP by using the formula given by Watson (1947) and expressed as follows:

$$
\text { LAI }=\frac{\text { Total Leaf Area }\left(\mathrm{cm}^{2}\right)}{\text { Canopy of the plant }\left(\mathrm{cm}^{2}\right)}
$$

\section{Harvest index}

Harvest index is calculated by using following formula given by Yoshida (1981).

$$
\mathrm{HI}=\frac{\text { Economic yield }}{\text { Biological yield }}
$$

\section{Net Assimilation Rate (NAR)}

It indirectly indicates the rate of net photosynthesis. It is expressed as ( $\mathrm{g}$ ) of dry matter produced per square meter of leaf in a day. It was computed by the formula given by Gregory (1926)

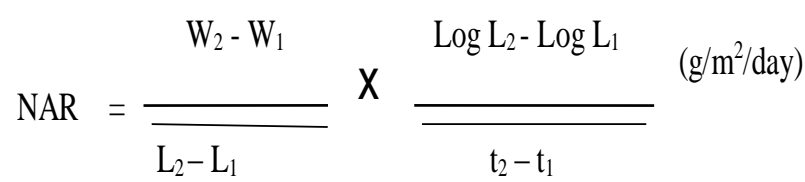

Where,

$\mathrm{W}_{1}$ and $\mathrm{W}_{2}$ refer to whole plant dry weight att 1 and $t_{2}$

$\mathrm{L}_{1}$ and $\mathrm{L}_{2}$ refer to leaf area on two successive periods at $t_{1}$ and $t_{2}$.

\section{Crop growth rate (CGR)}

CGR is the rate $\left(\mathrm{g} / \mathrm{m}^{2} /\right.$ day) of a crop growing (Gardner et al., 2010) as

$\mathrm{CGR}=\frac{\mathrm{W}_{2}-\mathrm{W}_{1}}{\mathrm{t}_{2}-\mathrm{t}_{1}}$ 
Where,

$\mathrm{W}_{1}$ and $\mathrm{W}_{2}$ refer to the whole plant dry weight on two successive periods at $t_{1}$ and $t_{2}$ respectively.

\section{Relative growth rate (RGR)}

RGR is the gram of dry matter produced by a gram of existing dry matter in a day and is calculated by formula given by Blackman (1919) as

RGR $=\frac{\log w_{2}-\log _{1}}{t_{2}-t_{1}}$

Where,

$\mathrm{W}_{1}$ and $\mathrm{W}_{2}$ refer to the whole plant dry weight on two successive periods at $t_{1}$ and $t_{2}$ respectively.

\section{Qualitative traits}

Starch content $(\%)$ of tuber: The tuber starch content was analyzed by following rapid titrimetric method as described by Moorthy and Padmaja (2002).

Dry matter percentage: Dry matter (DM) content was worked out by using the formula:

Dry matter percentage of the tuber = Dry weight of the tubers

Fresh weight of the tubers

X 100

\section{Results and Discussions}

\section{Physiological parameters}

\section{Leaf area index}

There were significant differences among the different treatments in respect to leaf area index. The leaf area index increased with the advancing of days and decreased at later stage of growth, which was due to the production of more number of leaves at early stages and later decreased due to senescence, mutual shading of leaves within the canopy caused decreased in growth. The highest leaf area index was observed in treatment CAUST-1 (0.98) at 120 DAP which was at par with treatment CAUST-2(0.95) and AAUST-3 (0.87). The minimum leaf area index was observed in treatment by $\mathrm{T}_{9}(0.69)$ which was followed by BCST-5 (0.72). This result was in conformity with the findings of Roy Chowdhury (1995).

\section{Harvest index}

The data on harvest index (\%) showed significant differences among the germplasm tested. The maximum harvest index was recorded from CAUST-1(77.67\%) which was at par with all the other treatments except BCST-13 (67.73 \%). The minimum harvest index was recorded from BCST-13(67.73\%). The high harvest index in the germplasm might be due to high leaf area with high DM production efficiency resulting to the high yield in swamp taro. The present finding was also supported by Roy Chowdhury (1995).

\section{Net assimilation rate}

In the experiment, there were significant differences among the treatments in respect to net assimilation rate. At 120 DAP, the maximum net assimilation rate was recorded from CAUST-1 $\left(0.00060 \mathrm{~g} / \mathrm{m}^{2} /\right.$ day $)$ which was at par with CAUST-2 (0.00058 $\mathrm{g} / \mathrm{m}^{2} /$ day $)$, AAUST-3(0.00055 g/m²/day), AAUST$1\left(0.00053 \mathrm{~g} / \mathrm{m}^{2} /\right.$ day $)$ and BCST-3(0.00053 $\mathrm{g} / \mathrm{m}^{2} /$ day). The minimum NAR was recorded from BCST-13(0.0040g/ $/ \mathrm{m}^{2} /$ day $)$. The germplasms showed lower rate of NAR at 120 days after planting might be due to shading of lower leaves. The results were in conformity 
with Sivan (1976) and Nandi and Sen (1998) in sweet potato.

\section{Crop growth rate and relative growth rate}

At 120 DAP, the maximum crop growth rate was recorded from CAUST- $1\left(1.249 \mathrm{~g} / \mathrm{m}^{2} /\right.$ day $)$ and the minimum crop growth rate was recorded from BCST-13(0.563 $\mathrm{g} / \mathrm{m}^{2} /$ day $)$. At 120 DAP, the maximum relative growth rate was recorded from CAUST-1 $(0.0049 \mathrm{~g} / \mathrm{g} /$ day $)$ which was at par with treatments CAUST$2(0.0048 \mathrm{~g} / \mathrm{g} / \mathrm{day})$ and AAUST-3(0.00440 $\mathrm{g} / \mathrm{g} /$ day). The minimum relative growth rate was recorded from $T_{9}(0.0041 \mathrm{~g} / \mathrm{g} /$ day $)$ which was followed by treatments $\mathrm{T}_{4} \quad(0.0042$ $\mathrm{g} / \mathrm{g} /$ day). In the active vegetative growth stages the RGR was increased and then gradually decreased at later stages of growth. These results were in conformity with the findings of Das et al., (1997).

Yield and yielding parameters at harvest (180 DAP)

Data on yield and yielding parameters at different stages of observation revealed that there were significant differences among the different treatments (Table 1 and 2).

Table.1 Physiological parameters of swamp taro germplasms at 120 DAP

\begin{tabular}{|c|c|c|c|c|c|}
\hline TREATMENTS & LAI & HI & NAR & CGR & RGR \\
\hline CAUST-1 & 0.98 & 77.67 & 0.00060 & 1.249 & 0.0049 \\
\hline CAUST-2 & 0.95 & 75.84 & 0.00058 & 1.121 & 0.0048 \\
\hline AAUST-1 & 0.78 & 73.50 & 0.00053 & 0.872 & 0.0042 \\
\hline AAUST-2 & 0.79 & 73.53 & 0.00046 & 0.698 & 0.0041 \\
\hline AAUST-3 & 0.87 & 76.67 & 0.00055 & 1.011 & 0.0044 \\
\hline BCST-1 & 0.81 & 70.23 & 0.00048 & 0.839 & 0.0042 \\
\hline BCST-3 & 0.75 & 71.08 & 0.00053 & 0.822 & 0.0041 \\
\hline BCST-5 & 0.72 & 72.76 & 0.00041 & 0.604 & 0.0042 \\
\hline BCST-13 & 0.69 & 67.73 & 0.00040 & 0.563 & 0.0041 \\
\hline S.Ed( \pm ) & 0.06 & 4.50 & 0.000033 & 0.059 & 0.0003 \\
\hline CD $(\mathbf{0 . 0 5})$ & 0.14 & 9.67 & 0.000069 & 0.125 & 0.0006 \\
\hline
\end{tabular}

Table.2 Yield attribute and quality of some germplasms of swamp taro at harvest (180 DAP)

\begin{tabular}{|c|c|c|c|c|c|c|c|c|}
\hline $\begin{array}{l}\text { Treatment } \\
\text { s }\end{array}$ & $\begin{array}{l}\text { Caudex } \\
\text { length } \\
\text { (cm) }\end{array}$ & $\begin{array}{c}\text { Caudex } \\
\text { yield/plo } \\
\text { t (kg) }\end{array}$ & $\begin{array}{l}\text { Diameter } \\
\text { of the } \\
\text { caudex } \\
(\mathrm{cm})\end{array}$ & $\begin{array}{l}\text { Number } \\
\text { of stolons }\end{array}$ & $\begin{array}{l}\text { Length of } \\
\text { stolons } \\
\text { (cm) }\end{array}$ & $\begin{array}{c}\text { Stolons } \\
\text { weight }(\mathrm{g})\end{array}$ & $\begin{array}{c}\text { Starch } \\
\text { content } \\
(\%)\end{array}$ & $\begin{array}{c}\text { Dry matter } \\
\text { percentage } \\
(\%)\end{array}$ \\
\hline CAUST-1 & 30.73 & 19.57 & 6.44 & 7.40 & 54.05 & 191.43 & 8.77 & 12.61 \\
\hline CAUST-2 & 30.67 & 19.23 & 5.90 & 8.60 & 50.20 & 194.49 & 7.17 & 13.66 \\
\hline AAUST-1 & 22.93 & 17.07 & 5.39 & 8.27 & 31.63 & 189.77 & 6.43 & 15.99 \\
\hline AAUST-2 & 18.80 & 14.90 & 4.63 & 7.13 & 33.95 & 177.74 & 6.50 & 11.20 \\
\hline AAUST-3 & 26.38 & 19.02 & 6.05 & 8.13 & 60.40 & 183.35 & 7.86 & 14.19 \\
\hline BCST-1 & 19.33 & 16.43 & 6.01 & 6.80 & 64.71 & 164.06 & 6.91 & 11.76 \\
\hline BCST-3 & 18.10 & 17.19 & 5.64 & 8.40 & 57.83 & 190.92 & 5.40 & 12.69 \\
\hline BCST-5 & 14.52 & 14.33 & 5.13 & 7.33 & 38.45 & 174.75 & 6.29 & 15.78 \\
\hline BCST-13 & 12.00 & 13.90 & 4.75 & 7.40 & 48.26 & 176.20 & 7.50 & 13.61 \\
\hline $\operatorname{S.Ed}( \pm)$ & 1.62 & 1.00 & 0.44 & 0.61 & 2.12 & 3.46 & 0.12 & 0.61 \\
\hline CD (0.05) & 3.42 & 2.13 & 0.93 & 1.29 & 4.51 & 7.33 & 0.26 & 1.29 \\
\hline
\end{tabular}


Among the treatments, the maximum length of the caudex at 180 DAP was recorded from treatment CAUST-1 $(30.73 \mathrm{~cm})$ which was at par with CAUST-2 $(30.67 \mathrm{~cm})$ and the minimum was recorded from the treatment BCST-13 $(12.00 \mathrm{~cm})$ which was at par with BCST-5 $(14.52 \mathrm{~cm})$. Similar observation in length of caudex was reported by Ramesh et al., (2017) in swamp taro. Maximum caudex yield per plot at 180 DAP was recorded from treatment CAUST-1 (19.57kg) which was at par with CAUST-2 (19.23kg) and AAUST-3 $(19.02 \mathrm{~kg})$. The minimum caudex yield per plot was recorded from the treatment BCST$13(13.90 \mathrm{~kg})$ which was at par with BCST-5 $(14.33 \mathrm{~kg})$ and AAUST-2 $(14.90 \mathrm{~kg})$. Due to increase in different plant characters like leaf area, plant height, number of leaves which caused increase in vegetative growth of the plant and photosynthetic rate. The caudex yield in swamp taro was dependent on its photosynthetic efficiency and this correlated with LAI and greater exposure to the sunlight. Similar finding was also reported by Roy Chowdhury (1995). The maximum diameter of the caudex was recorded from treatment CAUST-1 $(6.44 \mathrm{~cm})$ which was at par with AAUST-3 $(6.05 \mathrm{~cm}), \quad$ BCST-1 $(6.01 \mathrm{~cm})$, CAUST-2 $(5.90 \mathrm{~cm})$ and BCST $-3(5.64 \mathrm{~cm})$. The minimum diameter of the caudex was recorded from the treatment AAUST$2(4.63 \mathrm{~cm})$ which was at par with BCST-13 $(4.75 \mathrm{~cm})$, BCST-5 $(5.13 \mathrm{~cm})$ and AAUST$1(5.39 \mathrm{~cm})$. The present findings was also supported by Ruth and Ramaswamy (2001) in cassava. The maximum number of stolons was observed in CAUST-2 (8.60) which was at par with all the treatments except BCST-1 (6.80) and AAUST-4 (7.13). The minimum number of stolons was recorded from the treatment BCST-1(6.80) which was at par with AAUST-4 (7.13). The maximum stolon length was recorded from treatment BCST$1(64.71 \mathrm{~cm})$ which was at par with treatments AAUST-3 $(60.40 \mathrm{~cm})$ and the minimum stolon length was recorded from the treatment
AAUST-1 $(31.63 \mathrm{~cm})$. The maximum stolons weight was recorded from treatment CAUST$2(194.49 \mathrm{~g})$ which was at par with treatments CAUST-1 (191.43g), BCST-3(190.92g) and AAUST-1(189.77g). The minimum stolons weight was recorded from the treatment BCST-1 (164.06g) at 180 DAP. The results were in conformity with Mitra (2013) and Ramesh et al., (2017).

\section{Quality parameters}

From the experimentation of quality parameters among the treatments, it was observed that starch content in caudex was observed maximum from CAUST-1(8.77\%) which was significantly higher than the other treatment and the minimum caudex starch content $(5.40 \%)$ was recorded from BCST-3. From the present study, it was obtained that dry matter percentage (\%) was observed maximum from AAUST-1(15.99 \%) which was at par with BCST-5(15.78\%). The minimum dry matter percentage $(11.20 \%)$ was recorded from AAUST-2. The present findings were in agreement with the findings of Sen et al., (2006), Mitra (2013) and Ramesh et al., (2017). From the studies it can be concluded that among the treatments, treatment $\mathrm{T}_{1}$ (CAUST-1) was superior with respect to vegetative growth, yield and yielding parameter. For quality analysis, $\mathrm{T}_{1}$ (CAUST-1) and $\mathrm{T}_{1}$ (AAUST-1) recorded the highest starch content and dry matter content respectively.

\section{Acknowledgement}

The authors acknowledge the contributions of Joyshree Laishram, A.K. Bijaya Devi, K. James Singh and Lourembam Tinibala Devi, Department of Horticulture, College of Agriculture, Central Agricultural University, Imphal, Manipur (India) for their technical support and valuable contributions to the manuscript. 


\section{References}

Blackman, V.H. (1919). The compound interest law and plant growth. Ann. Bot., 33: 353-360.

Das, P.K., Sen, H., Banerjee, N.C. and Panda, P.K. (1997). Biomass production and growth rate at different phenophases of elephant foot yam as influenced by chemical treatments. Indian J. Agric. Res., 31: 115-121.

Gardner, F.P., Pearce, R.B. and Mitchell, R.L. (2010). Physiology of crops plants. Scientific Publishers, India, pp. 202205.

Gregory, F.P. (1926). The effect of climate condition on growth of barley. Ann. Bot., 40: 1-26.

Mitra, S. (2013). Morphological and nutritional diversity of Indian swamp taro (Colocasia esculenta var. stolonifera L. Schott). Tropical Agric., 90(1): 11.

Moorthy, S.N. and Padmaja, G. (2002). A rapid titrimetric method for the determination of starch content of Cassava tubers. J. Root Crops, 28(1): 30-37.

Nandi, S. and Sen, H. (1998). Evaluation of sweet potato [Ipomoea batatas (L.) Lam.] Cultivars under late planted situation. J. Root Crops, 24(1): 73-77.

Ramesh, M., Alam, S., Sarma, A. and Kalita, P. (2017). Genetic variability of Nalkachu genotypes. Bull. Env. Pharmacol. Life Sci., 6(2): 506-514.

Ramesh, M., Alam, S., Sarma, A. and Kalita, P. (2017). Morphological characterization of some Nalkachu genotypes. Bull. Env. Pharmacol. Life Sci., 6(2): 515-521.

Roy Chowdhury, S. (1995). Leaf area development in Colocasia and its relationship with yield. Indian $J$. Pl.Phsiol., 38: 305-308.

Roy Chowdhury, S., Anand, P.S.B., Kundu, D.K. and Kumar, A. (2010). A performance of swamp taro cultivars as affected by brief submergence. J. Root Crops, 36: 204-209.

Ruth, B. R., A. and Ramaswamy, N. (2001). Evaluation of open pollinated clones of cassava for growth and yield parameters. Prog. Hort., 33(1): 57-60.

Saud, B.K. and Baruah, R.K.S.M. (2000). Pani - kachu -special taro cultivation in Southern Assam. Intensive Agri., 38: 26-27.

Sen, H., Chattopadhyay, A. and Pal, S. (2006). Characterization of swamp taro landraces of eastern India. Hort. J., 19(2): 107-110.

Sivan, P. (1976). Dry matter accumulation and distribution in three cultivars of taro (Colocasia esculenta L. Schott.). AGRIS. 166.

Watson, D.J. (1947). Comparative physiological studies in growth of field crops. 1. Variation in net assimilation rate and leaf area between species and varieties, and within and between years. Ann. Bot., 11: 41-76.

Yoshida, S. (1981). Fundamentals of Rice Crop. International rice research institute, Los Banos, Laguna, Phillipines, pp. 61.

\section{How to cite this article:}

Joyshree Laishram, A.K. Bijaya Devi, K. James Singh and Lourembam Tinibala Devi. 2019. Evaluation of Swamp Taro [Colocasia esculenta var. Stoloniferum (L.) Schott] Germplasms on Physiology, Yield and Quality. Int.J.Curr.Microbiol.App.Sci. 8(07): 1184-1189. doi: https://doi.org/10.20546/ijcmas.2019.807.140 